\title{
CROSS-CULTURAL DIMENSIONS AND CROSS-CULTURAL ORIENTATIONS IN CONSTRUCTION PROJECTS: CASE STUDY OF SRI LANKA
}

\author{
NIRUSIKA RAJENTHIRAN ${ }^{1}$, MADHUWANTHI. H.A.S ${ }^{2}$, DISSANAYAKE. D.M.P.P³ \& SIRIMEWAN. \\ D.C. 4 \\ 1,3, 4Department of Building Economics, University of Moratuwa, Moratuwa, Sri Lanka \\ ${ }^{2}$ UniSA STEM, University of Australia, Adelaide, South Australia \\ 1vrnirusika@gmail.com, 2hasmadhuwanthi@gmail.com,3piumi2d@gmail.com,4dianis@uom.lk
}

\begin{abstract}
.
Significant issues affecting the success of construction projects due to globalisation is the establishment of a multicultural project team. Presently, China has emerged as one of Sri Lanka's main sources of foreign and commercial loans in an environment, where the island is seeking to rebuild and modernise infrastructure. However, the involvement of multicultural project teams often present unique challenges due to cross-cultural interactions, thereby, creating conflicts through construction projects, makes the conflict unavoidable. Therefore, this study was attempting to identify the cross-cultural dimensions and cross-cultural orientations in cross-cultural teamwork of Chinese contractors in construction projects in Sri Lanka. A qualitative approach was followed in this study in which multiple case study was selected as the most appropriate method for the research. Accordingly, semi-structured interviews were conducted among the selected four (4) respondents from each case to collect the data. Captured data was analysed by the manual content analysis method. An empirical investigation has been validated communication, leadership, trust, collectivism, team selection, uncertainty, team development and management as the common cross-cultural dimensions for all the three cases. This study added new crosscultural dimensions to the literature in the context of Sri Lankan construction industry namely, coordination, harmony and customs with specific cross-cultural orientations. The study can be further developed to investigate strategies to manage intragroup conflicts occurs in cross-cultural teamwork of Sri Lankans and Chinese professionals in the Sri Lankan construction industry.
\end{abstract}

Keywords: Construction projects, Cross-culture, Cross-culture dimensions, Cross-culture orientations, China, Sri Lanka

\section{Introduction}

In the construction industry, International Projects allow the industry of developing nations to evolve through the teamwork with firms of developed nations (Raftery et al., 1998). According to Xiao and Boyd (2010), the participation of other nationalities for the construction project works became manifestation due to the advance outlooks of design, materials, construction methods, technologies, teamwork and management aspects. However, in developing countries, when construction activities are heavily influenced by the foreign participants, cross-cultural interactions become a key role in negotiations, decision making, problem-solving and various other construction organisation transactions (Ochieng \& Price, 2009). Cross-cultural teamwork necessitates interrelations with team members, whose social aspects are prejudiced by other cultural significances corresponding to skills in communication, leadership, interpersonal (Pheng \& Leong, 2000). These cultural differences might create misunderstanding between people and businesses, forming conflict risks and making dissatisfaction among construction project participants (Tijhuis, 2011).

Intragroup conflicts play a foremost role in project delivery on time without delays (Ng et al., 2007). Conversely, foremost serious distinctive of the construction is the involvement of various nationalities invited as a cross-cultural team to perform work together in projects (Harmon, 2003). The project management team should enthusiastically concentration on avoiding and preventing conflict strategies in the cross-cultural team by considering cultural dimensions of different nationalities from rising conflict into claims, consequently further resolving claims to prevent from becoming as disputes (De Dreu \& Van Vianen, 2001).

The increased global nature of construction projects highlights the importance of multiculturalism that lead to successful project execution (Ochieng, \& Price, 2010). However, there is no consensus on empirical work that elaborate explicitly the extent to which cross-culture affects Sri Lankan construction industry. Therefore, this study investigates how cross-culture impact the teamwork by identifying the cross-cultural dimensions and cross-cultural orientations in cross-cultural teamwork of Chinese contractors in construction projects in Sri Lanka. 


\section{Nature of Cross-Cultural Projects in the Construction Industry}

International construction projects consist of contractors, consultants, and employers coming from multi-cultural backgrounds, at least one of which works outside the country of origin (Chan \& Suen, 2005). The construction industry shall make the optimum use of international construction opportunities and contribute to the development of materials, plants and equipment, project documents and procedures, human resources, technology and institutions (Ofori, 2000).

Cross-cultural construction project teams have a common set of values and beliefs, where beliefs refer to people's perceptions on how things are done in an organisation and are reported as "practices" in a particular culture and values refers to the way that the people think about how things should be done correspondingly in their preferred practices (Ochieng \& Price, 2009). Socioeconomic and cultural changes are increasingly confusing, and the globalisation of the construction industry has brought many challenges to project stakeholders at all levels (Lewis, 2007). In overseas construction projects, organisations must help their project managers to understand the international context and improve their ability to understand everyday issues from a variety of cultural perspectives (Ochieng \& Price, 2009). Differences in values, attitudes, perceptions, and behavioural norms affect the people, who are working in a cross-cultural environment in numerous ways (Xiao \& Boyd, 2010).

Global construction projects involving collaborations between participants from multiple countries often creating unique challenges and cost overruns due to cross-border interactions (Mahalingam \& Levitt, 2007). Coordination of key behavioural dimensions refers to the coordination and integration of culture and project participants in different levels, helping project participants to understand the interaction of their behaviours and ensuring all project members work together to achieve common goals (Nguyen, 2019). When managing multicultural teams, these are synthesised into a framework of eight key dimensions to consider (Ochieng \& Price, 2009), which are discussed in the next section.

\section{Cross-Cultural Dimensions and Orientations}

Major distinctive of the construction is the involvement of various nationalities incurred as a crosscultural team to perform to work together with the aids of project scope (Harmon, 2003). Managing cross-cultural teams in the construction industry need to consider every nationality specific cultural value (Ochieng \& Price, 2009). Table 1 shows eight types of cross-cultural dimensions together with their cross-cultural orientations identified in the previous research.

Table 1. Cross-cultural dimensions and the associated cross-cultural orientations

\begin{tabular}{|c|c|c|c|c|}
\hline $\begin{array}{l}\text { Cross-cultural } \\
\text { dimensions }\end{array}$ & Description & $\begin{array}{l}\text { Source } \\
\text { of } \\
\text { refere } \\
\text { nce }\end{array}$ & $\begin{array}{l}\text { Cross- } \\
\text { cultural } \\
\text { orientations }\end{array}$ & $\begin{array}{l}\text { Sources of } \\
\text { reference }\end{array}$ \\
\hline Communication & $\begin{array}{l}\text { Communication in projects helps build } \\
\text { and maintain relationships by team } \\
\text { effectiveness [2] }\end{array}$ & $\begin{array}{l}{[2],[6],} \\
{[8],[9],} \\
{[10],} \\
{[11]}\end{array}$ & $\begin{array}{l}\text { Emotional } \\
\text { dependence } \\
\text { Team } \\
\text { effectiveness } \\
\text { Language } \\
\text { Empathy }\end{array}$ & $\begin{array}{l}1],[5],[7] \\
{[3],[4],[6]} \\
{[1],[3],[4],} \\
{[5]} \\
{[3],[5]}\end{array}$ \\
\hline Leadership & $\begin{array}{l}\text { Cross-cultural leadership style makes } \\
\text { team members share their own opinions, } \\
\text { ideas and attention with the leader that } \\
\text { can helpful for the efficient project } \\
\text { performance [6] }\end{array}$ & $\begin{array}{l}{[2],[4],} \\
{[8],[9]}\end{array}$ & $\begin{array}{l}\text { Responsive } \\
\text { Inspirational } \\
\text { Charismatic } \\
\text { Attention } \\
\text { Confidence }\end{array}$ & $\begin{array}{l}{[2],[5],[7]} \\
{[5]} \\
{[1],[5],[7]} \\
{[7]} \\
{[1],[2],[3],} \\
{[5],[7]}\end{array}$ \\
\hline Trust & $\begin{array}{l}\text { Cross-culture team members need to } \\
\text { concern for the trustworthy to meet } \\
\text { expectation induced by oppression [2] }\end{array}$ & $\begin{array}{l}{[2],[6],} \\
{[11]}\end{array}$ & $\begin{array}{l}\text { Concern } \\
\text { Obey } \\
\text { Trustworthy }\end{array}$ & $\begin{array}{l}{[2],[4]} \\
{[1],[3],[5]} \\
{[1],[2],[4]}\end{array}$ \\
\hline
\end{tabular}




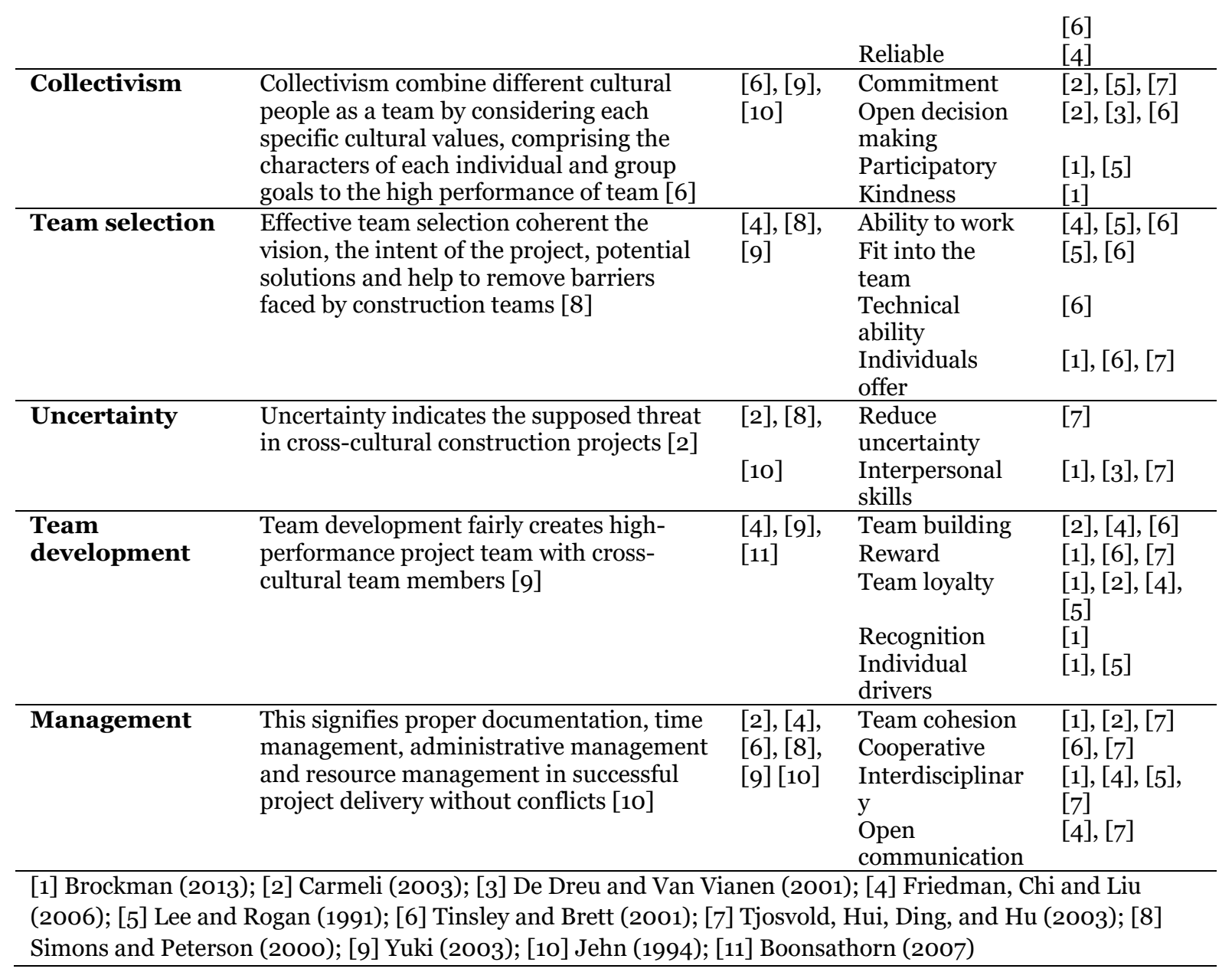

\section{Chinese Culture into Sri Lankan Construction Projects}

In the current context, Sri Lanka has been identified as a foremost concern country for the construction by foreign countries due to its irreplaceable location and economic growth. Additionally, Hillman (2018) supported that China has become an attractive economic partner to the Sri Lankan construction industry. Furthermore, the author expressed that hasty socio-economic improvement and high-rise construction projects are currently under construction by China. Huge investments, a combination of contractual provisions and numerous stakeholders with various nations are these significant features of Chinese involvement to the construction industry.

Pheng and Leong (2000) found Chinese cultural characteristics, which Sri Lankans need to be aware of while working as a team as trust, emotional dependence, honest and gratitude. Those are the significant values that substantially rely on the contracts both locally and internationally between the parties to the contracts. Chinese culture is deeply influenced by team development, which built on loyalty, team building and leadership that came from a morally superior individual, who does virtuous performances and all these features ask for collectivism in favour of harmony in a community (Chan, 1997).

\section{Research Methodology}

The study aimed to identify the cross-cultural dimensions and cross-cultural orientations in crosscultural teamwork of Chinese contractors in construction projects in Sri Lanka. Thus, the research question of the study was 'what are the cross-cultural dimensions and cross-cultural orientations in Chinese cross-cultural teamwork in international construction projects in Sri Lanka?' An exploratory 
case study is selected as the research strategy, "what" type of research questions are supported by exploratory, which can be developed further, into theories propositions relating to the study (Yin, 2009). Accordingly, three ongoing multi-complex projects in Sri Lanka were selected as cases in this study. Table 2 summarizes the profile of selected cross-cultural construction projects in Sri Lanka. Every project consist team consisted of a Chinese contractor as the main contractor and Sri Lankans work as the consultant. These projects build by Chinese contractors under the supervision of Sri Lankan Consultants. Four respondents were selected from the top management, where two respondents from the contracting organisation and the rest were from the consulting organisation. Semi-structured interviews were conducted to collect the data and the captured data was analysed by the manual content analysis method. Table 3 presents the respondent's details in three cases.

\section{Table 2. Profile of the Cases}

\begin{tabular}{|c|c|}
\hline Case & Description \\
\hline Case A & $\begin{array}{l}\text { - Hotel and Residences complex } \\
\text { - } \quad \text { Comprises of } 42 \text { storey hotel and } 30 \text { storey residence } \\
\text { - To be completed by } 2021\end{array}$ \\
\hline Case B & $\begin{array}{l}\text { - Residences and office complex } \\
\text { - Comprises of 50-storey office tower and residence with a } \\
\text { shopping mall } \\
\text { - To be completed by } 2020\end{array}$ \\
\hline Case & $\begin{array}{l}\text { - Hotel and Residences Complex } \\
\text { - Comprises of } 55 \text {-storey residential, } 29 \text { storey hotel with a } \\
\text { shopping mall } \\
\text { - To be completed by } 2021\end{array}$ \\
\hline
\end{tabular}

Table 3. Profile of the Respondents

\begin{tabular}{|c|c|c|c|}
\hline Case & $\begin{array}{l}\text { Respondent's } \\
\text { code }\end{array}$ & Designation & $\begin{array}{l}\text { Work } \\
\text { experience }\end{array}$ \\
\hline $\begin{array}{l}\varangle \\
ঠ \\
\mho \\
\mho \\
\mho\end{array}$ & $\begin{array}{l}\text { A1 } \\
\text { A2 } \\
\text { A3 } \\
\text { A4 }\end{array}$ & $\begin{array}{l}\text { Chartered Quantity Surveyor } \\
\text { Planning Engineer } \\
\text { Site Engineer } \\
\text { Senior Quantity Surveyor }\end{array}$ & $\begin{array}{l}15 \text { years } \\
10 \text { years } \\
13 \text { years } \\
18 \text { years }\end{array}$ \\
\hline 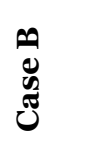 & $\begin{array}{l}\mathrm{B} 1 \\
\mathrm{~B} 2 \\
\mathrm{~B} 3 \\
\mathrm{~B} 4\end{array}$ & $\begin{array}{l}\text { Senior Quantity Surveyor } \\
\text { Site Engineer } \\
\text { Project Manager } \\
\text { Planning Engineer }\end{array}$ & $\begin{array}{l}15 \text { years } \\
18 \text { years } \\
20 \text { years } \\
15 \text { years }\end{array}$ \\
\hline 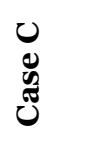 & $\begin{array}{l}\mathrm{C} 1 \\
\mathrm{C} 2 \\
\mathrm{C} 3 \\
\mathrm{C} 4\end{array}$ & $\begin{array}{l}\text { Chartered Quantity Surveyor } \\
\text { Planning Engineer } \\
\text { Project Manager } \\
\text { Site Engineer }\end{array}$ & $\begin{array}{l}17 \text { years } \\
15 \text { years } \\
25 \text { years } \\
13 \text { years }\end{array}$ \\
\hline
\end{tabular}

\section{Research Findings and Analysis}

\subsection{CURRENT LEVEL OF CHINESE CROSS-CULTURAL TEAMWORK WITH SRI LANKANS}

All the respondents in three cases agreed that the involvement of the foreign workforce has been increased in the Sri Lankan context. This is because of the need for high skilled and technical knowledge among workers as highlighted in Case A. Further, Case $\mathrm{C}$ respondent added unavailability of construction materials results to make arrangements with foreign suppliers. Therefore, working with foreign participants has become a success and it enhances the construction team members to work with the cross-cultural team. However, Case B emphasised communication barriers, cultural differences, time-consuming approvals hinder the cross-cultural teamwork in Sri Lanka. 


\subsection{CROSS-CULTURAL DIMENSIONS AND CROSS-CULTURAL ORIENTATIONS}

With the development of globalisation and the internationalisation of the construction industry, China and Sri Lanka subordinate closely with each other in aspects of construction. Managing cross-cultural teams in the construction industry need to consider the specific cultural values of every nationality. Accordingly, the various cross-cultural dimensions identified in the literature were further elaborated by the respondents in the perspective of international construction projects in Sri Lanka. Besides, several new cross-cultural dimensions and cross-cultural orientations were found from the expert opinion survey, as discussed in next.

\subsubsection{Communication}

'Lack of communication' was stated as a cross-cultural dimension by all respondents from all Cases. 'Meetings decision are made in Chinese languages' and 'difficult to argue their viewpoints on their own languages' were identified as reasons for communication barriers in Case A and Case B, respectively. Respondent A2 disclosed, 'non-adherence to cross-cultural communication and misunderstanding of communication with Chinese and Sri Lankan people causes intragroup conflicts'. Respondent B3 further acknowledged that they are facing issues mainly due to language barriers between Chinese and Sri Lankans, as it was the main reason for occurring conflicts in cross-cultural projects. Case $\mathrm{C}$ was not considered that this become challenge for them, where they are well-developed mobile device use as a translator and all decisions are made in the English language as it is common for Sri Lankan and Chinese. Respondent $\mathrm{C}_{4}$ expressed that the cooperation between cross-cultural team members is essential for proper interpretation of information passing through the cross-cultural team members.

\subsubsection{Leadership}

Cross-cultural dimension, 'Leadership' was notified by all the three cases. The respondents from all the cases agreed that 'differing opinions coming from superiors' and 'confusion on different roles of team members' were the main reasons for the intragroup conflicts due to cross-cultural teamwork, which can be overcome through proper leadership. Further, B3 expressed that the unclear instructions and information by other party or the supervisor result in poor leadership within crosscultural team members of Chinese and Sri Lankans'. Besides, respondents from Case A and Case C emphasised 'influence of personal skills' and 'team member's well-being' also influence intragroup conflicts in cross-cultural teamwork. Moreover, $\mathrm{C} 4$ stated that "leadership behaviours are associated with distinct cultural traits, which reduce the charismatic and brush up the knowledge of us about different cultures".

\subsubsection{Trust}

'Trust' was notified by all the respondents as a cross-cultural dimension. All the respondents in the three cases agreed that the major reason for the intragroup conflicts in cross-cultural teamwork due to trust effect the reliability and trustworthiness. A1 expressed that 'differing opinions of cross-cultural teamwork professionals and apprehension between Chinese and Sri Lankans are affected by trust'. Similarly, according to Case A and Case B 'intolerance among team members' was the main reason for the intragroup conflicts due to cross-cultural trust by Chinese and Sri Lankans. Trust among team members validated by respondents $\mathrm{B}_{4}$ and $\mathrm{C}_{3}$ as they are concerned about developing successful relationships within cross-cultural team members of Chinese and Sri Lankans by taking their time and concerning their recent past performance.

\subsubsection{Collectivism}

Cross-cultural dimension, 'collectivism' was notified by all the respondents in the three cases. According to cases A and C, 'self-identity' and 'interaction among individuals from various national backgrounds' were the agreed factors, which influence the intragroup conflicts due to cross-cultural 
collectivism by Chinese and Sri Lankans. Collectivism among team members validated by B3, as they were always giving the priority to the needs of cross-cultural team members, associated with indirect and passive communication. Respondent $\mathrm{C}_{3}$ stated that 'we are giving priority to work as collectivism rather than individualism' by highlighting the positive impact to the cross-cultural teamwork of Chinese and Sri Lankan people. From the outcome of the study, kindness and equity were added as cross-cultural orientations for collectivism in this research.

\subsubsection{Team Selection}

'Team selection' was stated as a cross-cultural dimension by all the respondents from all the cases. In cases $\mathrm{B}$ and $\mathrm{C}$, the respondents have identified that 'ignoring team resolutions' creates intragroup conflicts between Chinese and Sri Lankans. Respondent A3, further mentioned that 'improper team selection', 'fewer opportunities for creativity', and 'irregular operating procedures for timeliness works on-site' cause intragroup conflicts within the cross-cultural team. Moreover, B2 expressed that information gaps between team members discourage the work progress within the project and underestimate the value of tolerance and politeness, thereby occurring intragroup conflicts between Chinese and Sri Lankan people.

\subsubsection{Uncertainty}

The 'uncertainty' was notified by all the respondents in the three cases as a cross-cultural dimension. Uncertainty affects the cross-cultural construction projects in ways of concern for efficiency, socioeconomic stress, formal and informal values, the ways of communication and behaviour within the project environment, collaboration in the supply chain while indicating the need to address cultural complexity in cross-cultural construction projects. Respondent A2 signified, improper management of inherent uncertainty' as the main reasons for the intragroup conflicts. B1 expressed more causes for this as 'failure of carrying out a task in construction' and the 'ways of communication patterns with other nation's professionals'.

\subsubsection{Team development}

Cross-cultural dimension, 'team development' was reported by all the respondents in three cases. Case $\mathrm{C}$ highlighted, cultural diversity and sharing of responsibilities to optimise team performance as the major reasons for the intragroup conflicts in cross-cultural teamwork. The respondents of case A indicated, 'gratitude of team members' and 'individual drivers' positively impact the team development of cross-cultural teams of Chinese and Sri Lankans. Also, B1 and B3 proposed to illuminate the cultural variances to expedite the understanding and enhance the team performance.

\subsubsection{Management}

Cross-cultural dimension, the 'management' was also reported by all the respondents from three cases. In Case A, A1 argued that the lack of open communication was a barrier to present their ideas and work cooperatively within cross-cultural teams. According to B2, low-level team cohesion influences the time, work and cultural change in the cross-cultural projects while lacking comprehension effects poor management within the team. In Case $\mathrm{C}$, all the respondents confirmed, team development affects the clear identification of project objectives and construction methodologies while emphasising the need of managing the culture to enhance the performance of cross-cultural construction project teamwork.

\subsubsection{Customs}

Cross-cultural dimension, 'customs' was additionally notified from Case B. It needs to be managed the challenges and minimise the misconducts within team members in a kindly manner to cope with various traditions for the success of project progress by avoiding conflicts. B2 supported this by stating, 'our team members shall react in a manner to avoid complications, when working with 
Chinese people. This was further validated by $\mathrm{B} 4$ as the Chinese people always give priority to the effective construction process, international operations management and negotiations.

\subsubsection{Coordination}

'Coordination was added as a new cross-cultural dimension by case A respondents as an addition to the literature findings. This needs mutual understanding within team members for successful project delivery. A3 highlighted that 'flexibility of our team members to present their problems, ideas, thoughts and opinions also need to be considered, when working with Chinese people'. This statement was further validated by A4, as they always give priority to work done rather than considering documentary. And also, they always allow team members to work with flexible manner.

\subsubsection{Harmony}

'Harmony' was identified as another cross-cultural dimension from cases A and B, which was not found in the literature. A2 said, 'values, beliefs, opinions and moral within team members need to be considered, when working with Chinese as they are always giving the priority to others opinions, which gives positive values for their works related to construction'. A4 mentioned that 'valuing longterm co-operation for our mutual benefits also affects cross-cultural teamwork'. Respondent B2, from case B, expressed that 'hierarchy of the Chinese is different from our hierarchy as they give priority to their hierarchical arrangement for a particular construction project than us'.

\section{Discussion}

The case study approach aimed to analyse the cross-cultural dimensions and cross-cultural orientations faced by cross-cultural team members of Sri Lankans and Chinese on construction projects in Sri Lanka. Altogether eleven cross-cultural dimensions regarding cross-cultural teamwork were identified in the perspective of the Sri Lankan context. All the respondents from the three cases mentioned that communication, leadership, trust, collectivism, team selection, uncertainty, team development and management are cross-cultural dimensions in the cross-cultural projects. In addition to the literature findings, cases A and B added 'harmony' as a new cross-cultural dimension, whereas 'coordination' and 'customs' were added from case A and case B respectively as they were not recognised from the previous research. The comparison of literature and case study findings were presented in Table 3 through pattern matching effort. 'Chinese cross-cultural teamwork' was highlighted by all the respondents from three Cases. It was evident in Case A that the occurrences of a result, when the team members having dissimilar cultures come into perpetual interaction of construction projects, with subsequent changes in the original cultural patterns of teams. Case B highlighted that the cross-cultural adaptation process possess different cultures from Sri Lanka and China, thus, the team members should deliberate from two dimensions to keep the traditional culture and distinctiveness orientations in cross-cultural dimensions.

Table 3. Pattern matching of findings

\begin{tabular}{cccc}
\hline & $\begin{array}{c}\text { Cross-cultural } \\
\text { dimensions }\end{array}$ & \multicolumn{2}{c}{ Cross-cultural orientations } \\
\cline { 3 - 4 } & Communication & Literature Findings & Case study Findings \\
\hline & $\begin{array}{c}\text { Emotional dependence, } \\
\text { Team effectiveness, } \\
\text { Language, Empathy } \\
\text { Responsive, } \\
\text { Inspirational, }\end{array}$ & Honesty, Respect, Cooperation \\
& $\begin{array}{c}\text { Charismatic, Attention, } \\
\text { Confidence } \\
\text { Concern, Obey, }\end{array}$ & Authoritarian, Personal skills, Well-being \\
Trust & $\begin{array}{c}\text { Trustworthy, Reliable } \\
\text { Commitment, Open } \\
\text { decision making, }\end{array}$ & Faithful, Integrity, Goodwill \\
& Collectivism & Equity
\end{tabular}




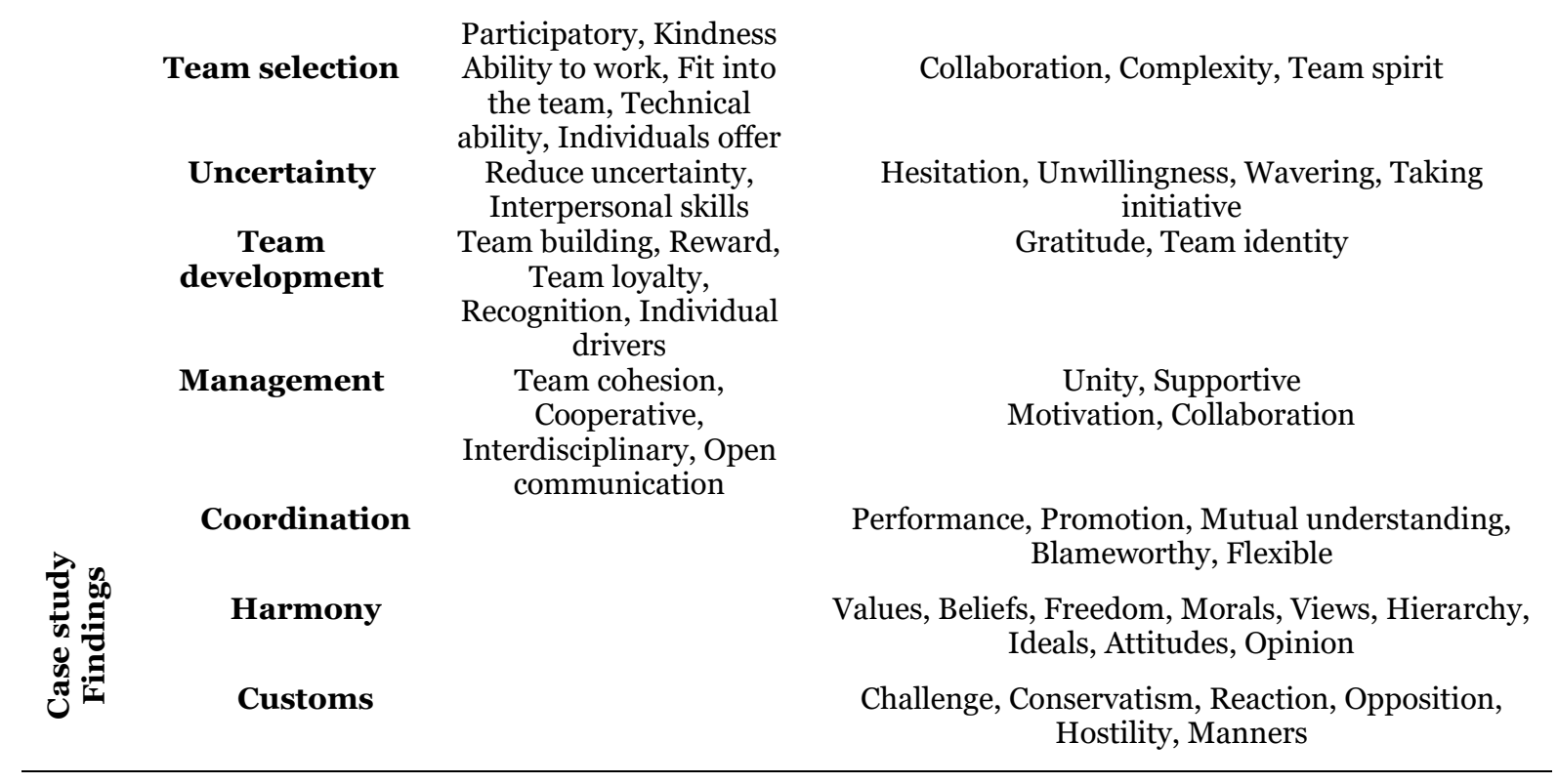

\section{Conclusion}

With the economic growth, Sri Lankan construction industry collaborates with Chinese construction professionals to uplift the construction industry. This multiculturalism allows new solutions for the lack of skilled workforce and technological improvements. In international context, 'Communication', 'Leadership', 'Trust', 'Collectivism', 'Team selection', 'Uncertainty', 'Team development', and 'Management' were identified as cross-cultural dimensions. Cross-cultural dimensions of Chinese cross-cultural teamwork, identified in the Sri Lankan context are in line with an international perspective. In addition to the findings of the literature, 'Coordination', 'Harmony' and 'Customs' were also highlighted as cross-cultural dimensions in the Sri Lankan context through case studies. Crosscultural orientations related to relevant cross-cultural dimensions are acknowledged in this research. Further, this study added new cross-cultural orientations to the literature as signified in Table 3. As an example, for the cross-cultural dimension 'Communication'; 'Emotional dependence', 'Team effectiveness', 'Language' and 'Empathy'. Moreover, 'Honesty', 'Respect' and 'Cooperation' were identified as cross-cultural orientations associated with 'Communication' as specific to the Sri Lankan context. Similarly, a range of cross-cultural orientations was identified relating to the cross-cultural dimensions elaborated in the study. This study aimed to present cross-cultural dimensions and crosscultural orientations in cross-cultural teamwork of Chinese contractors in Sri Lankan construction projects which have not been discovered as facts in the existing literature. The outcome of the study can be used to analyse the relationship between intragroup conflicts and cross-cultural dimensions in construction projects in Sri Lanka.

\section{References}

Boonsathorn, W. (2007). Understanding conflict management styles of Thais and Americans in multinational corporations in Thailand. International Journal of Conflict Management, 18(3), pp. 196-221.

Carmeli, A. (2003). The relationship between emotional intelligence and work attitudes, behavior and outcomes. Journal of Managerial Psychology, 18(8), pp. 788-813.

Chan, E. H. W. \& Suen, H. C. H. (2005). Dispute resolution management for international construction projects in China. Management Decision, 43(4), pp. 589-602.

Chan, E. W. (1997). Amicable dispute resolution in the PRC: implication for foreign-related construction disputes. Construction Management and Economics, 15(6), pp. 539-548.

DeChurch, L. A. \& Marks, M. A. (2001). Maximizing the benefits of task conflict: The role of conflict management. International Journal of Conflict Management, 12, pp. 4-22.

Friedman, R., Chi, S. C. \& Liu, L. A. (2006). An expectancy model of Chinese-American differences in conflict-avoiding. Journal of International Business Studies, 37(4), pp. 572-573. 
Harmon, K. J. (2003). Resolution of construction disputes: A review of current methodologies. Leadership Manage. Eng., $3(4)$, pp. 187-201.

Hillman, J.E. (2018). The Hazards Of China's Global Ambitions. New Perspectives Quarterly, 35, 17-20. doi:10.1111/npqu.12134

Jehn, K. A. (1995). A multi-method examination of the benefits and detriments of intragroup conflict. Administrative Science Quarterly, pp. 256-282.

Lewis, T. M. (2007). Impact of globalization on the construction sector in developing countries. Construction Management and Economics, 25(1), pp. 7-23.

Mahalingam, A. \& Levitt, R. E. (2007). Institutional theory as a framework for analyzing conflicts on global projects. Journal of Construction Engineering and Management, 133(7), pp. 517-528.

Mason, M. (2010). Sample size and saturation in PhD studies using qualitative interviews. In Forum: qualitative social research, Vol.11 No.3. Retrieved from http://dx.doi.org/10.17169/fqs-11.3.1428

Nguyen, L. H. (2019). Relationships between critical factors related to team behaviors and client satisfaction in construction Project Organizations. Journal of Construction Engineering and Management, 145(3), pp. 04019002.

Ochieng, E. \& Price, A. (2010). Managing cross-cultural communication in multicultural construction project teams: The case of Kenya and UK. International Journal of Project Management, 28(5), pp. 449-460.

Ochieng, E. G. \& Price, A. D. (2009). Framework for managing multicultural project teams. Engineering, Construction and Architectural Management, 16(6), pp. 527-543.

Ochieng, E. G. \& Price, A. D. (2009). Framework for managing multicultural project teams. Engineering, Construction and Architectural Management, 16(6), pp. 527-543.

Ofori, G. (2000). Globalization and construction industry development: research opportunities. Construction Management and Economics, 18(3), pp. 257-262.

Pheng, L. S. \& Leong, C. H. (2000). Cross-cultural project management for international construction in China. International Journal of Project Management, 18(5), pp. 307-316.

Raftery, J. et al. (1998). Globalization and construction industry development: implications of recent developments in the construction sector in Asia. Construction Management and Economics, 16(6), pp. 729-737.

Simons, T. L. \& Peterson, R. S. (2000). Task conflict and relationship conflict in top management teams: The pivotal role of intragroup trust. Journal of Applied Psychology, 85(1), pp. 102-111.

Tijhuis, W. (2011). Developments in construction culture research: Overview of activities of CIB w112 'culture in construction. Journal of Quantity Surveying \& Construction Business, 1(2), pp. 66-76.

Tinsley, C. H. \& Brett, J. M. (2001). Managing workplace conflict in the United States and Hong Kong. Organizational Behavior and Human Decision Processes, 85(2), pp. 360-381.

Xiao, H. \& Boyd, D. (2010). Learning from cross-cultural problems in international projects: a Chinese case. Engineering, Construction and Architectural Management, 17(6), pp. 549-562.

Yin, R. K. (2003). Case study reserach: Design and methods. 3 ed. s.l.:Sage.

Yin, R. K., (2014). Case study research: Design and methods. 5 ed. Thousand Oaks: Sage Publications.

Yuki, M. (2003). Intergroup comparison versus intragroup relationships: A cross-cultural examination of social identity theory in North American and East Asian cultural contexts. Social Psychology Quarterly, 66, pp. 166-183. 